\title{
Correlates of Family Farming Efficiency of Women Headed Households in Tumakuru District, India
}

\author{
D. Harshitha ${ }^{1 *}$, V.L. Madhu Prasad ${ }^{2}$ and Sanjay Yadav ${ }^{1}$ \\ ${ }^{1}$ Department of Agricultural Extension, University of Agricultural Sciences, \\ Bengaluru -560065 , India \\ ${ }^{2}$ Directorate of Extension, University of Agricultural Sciences, Bengaluru-56002, India
}

*Corresponding author

\section{Keywords \\ Family farming efficiency, Women headed households, Family farming \\ Article Info \\ Accepted: \\ 12 October 2019 \\ Available Online: \\ 10 November 2019}

\section{A B S T R A C T}

The present study was conducted during the year 2017-18 in purposively selected Tumakuru district comprising of three agro- climatic zones. From each zone, two taluks and from each taluk two hoblis were selected based on the major crop farming systems. From each hobli, list of villages having maximum number of women headed households practicing family farming was prepared in consultation with staff of Raitha Samparka Kendras (RSKs), Grama Panchayath and local leaders. Further four to eight villages and two to four respondents from each village were purposively selected by using 'snow ball technique' thus making total sample of 160.Data were gathered through structured interview schedule and analyzed using appropriate statistical tools. The study revealed that characteristics such as land holding, achievement motivation, adjustability, mass media use, deferred gratification, farming commitment, extension orientation, family size, livestock possession, material possession, credit orientation and risk orientation had positive and significant relationship with family farming efficiency. Similarly, with respect to extent of contribution of independent variables indicated that 12 out of 16 independent variables such as family size, land holding, livestock possession, material possession, credit orientation, mass media use, deferred gratification, achievement motivation, risk orientation, adjustability, farming commitment and extension orientation had contributed significantly towards family farming efficiency of women headed households. The $\mathrm{R}^{2}$ value indicated that all the 16 independent variables had contributed to the tune of 79.15 per cent of variation in family farming efficiency of women headed households. Further, Path analysis was applied to know the direct and indirect effects of independent variables on family farming efficiency of women headed households. As regards to the direct effects on family farming efficiency is concerned, land holding, credit orientation, material possession and livestock possession obtained four ranks in the same order. Further, ranking of variables based on their total indirect effects revealed that land holding, mass media use, achievement motivation and material possession had highest indirect effect. The first largest indirect effect was channeled through land holding, livestock possession and risk orientation. The residual effect was found to be 0.2085 . 


\section{Introduction}

Family farming is a means of organizing all agricultural and allied activities which is managed and operated by a family and is predominantly reliant on family labour, including women, men and children (Jose Graziano Da Silva., 2014). The declaration of the 2014 as the International Year of Family Farming by United Nations reflects a growing global consensus that family farming is key to feeding a world population that is expected to reach more than nine billion by 2050 .

In India, women are major producer of food because, agriculture is largely house hold enterprise. Further, women end up heading household were often found to be absence of a resident male head due to widowhood, divorce, separation, desertion, lack of mature sons to take over the households, migration of male member for long periods or loss of economic function by resident males due to disability and illness. The portion of women headed households in India has been raising. According to the census 2011, a total of 23 million, 19.65 lakh and 8412women headed households exist in rural India, Karnataka and Tumakuru district respectively (Anon, 2011). The family farming efficiency of women headed households depends on the work carried out by women, men and children. Hence, there is a need to elevate the women headed households to improve living conditions in rural areas. With this background, the present study has been taken up to ascertain the relationship between family farming efficiency with personal, psychological and socio-economic characteristics of family headed women.

\section{Materials and Methods}

The study was conducted in the purposively selected Tumakuru district of Karnataka state. The district comprising of three agro- climatic zones from each zone, two taluks were selected namely (1) Central Dry Zone (Sira and Madhugiri), (2) Eastern Dry Zone (Tumakuru and Gubbi) and (3) Southern Dry Zone (Turuvekere and Kunigal). From each taluk, two hoblis were selected based on the potential crop farming systems. Further, from each hobli, list of villages having maximum number of women headed households practicing family farming was prepared by consulting staff of Raitha Samparka Kendras (RSKs), Grama Panchayath, Anganavadi workers and local leaders. Further, arranged the villages in descending order and top four to eight villages in the list were selected. From each village, list of women headed households practicing family farming was prepared by using snow ball technique. From the list, two to four respondents were purposively selected thus making total sample of 160.The study was conducted by using ex-post facto research design. The correlation test, multiple regression and path analysis were carried out to know the relationship between independent variables and dependent variables.

\section{Relationship between personal, psychological and socio-economic characteristics of family headed women with their family farming efficiency}

The results pertaining to relationship between Personal, Psychological and Socio-economic characteristics of family headed women with their Family Farming Efficiency were presented in table 1.

It could be observed from the results that 12 out of 16 characteristics were found to have significant relationship with family farming efficiency. The independent variable land holding, achievement motivation, adjustability, mass media use, deferred gratification, farming commitment and extension orientation had positive and significant relationship with family farming 
efficiency at one per cent level. Similarly, the independent variables such as family size, livestock possession, material possession, credit orientation and risk orientation had positive and significant relationship with family farming efficiency at five per cent level. The remaining variables viz., age, education, annual income and scientific orientation had non-significant relationship with family farming efficiency

The possible reasons for the independent variables having significant relationship with family farming efficiency are given in ensuing paragraphs

\section{Land holding and family farming efficiency}

Land holding found to have positive and significant relationship with family farming efficiency. It is quite possible that family headed women with largest holdings evince keen interest and receptive to know about new farm practices and ideas, thus leading to efficiency in family farming Therefore, size of land holdings might have shown positive and significant relationship with family farming efficiency. The results are in accordance with the findings of Rajashekhar Reddy (2006), Basavaraj Gundappagol (2014) and Rahul Pawar (2015).

\section{Achievement motivation and family farming efficiency}

When family headed women have strong motivation to achieve in farming it drives her to excel in better utilization of resources without wasting thus it helps in achieving family farming efficiency. Therefore, achievement motivation might have shown positive and significant relationship with family farming efficiency. The results of the study are corroborated with the findings of Rajashekhar Reddy (2006).

\section{Adjustability and family farming efficiency}

Adjustability found to have positive and significant relationship with family farming efficiency. The probable reason might be due to ability of the family headed women to adjust with variations in the surrounding environment because when an individual came out of the comfort zone bound to adjust in prevailing condition therefore, it might have shown positive and significant relationship with family farming efficiency. However, there are no studies available either to support or contradict the obtained result.

\section{Mass media use and family farming efficiency}

Mass media use found to have positive and significant relationship with family farming efficiency. The possible reasons might be due to the higher exposure to mass media would facilitate the family headed women to develop the habit of gathering more information about new practices through radio, newspaper and other literature. Mass media also provides enormous opportunity for repeated exposure to new technologies and motivating growers and enhances the efficiency in family farming. The findings are supported by the results of Nehete et al., (2011) and Basavaraj Gundappagol (2014).

\section{Deferred gratification and family farming efficiency}

Deferred gratification found to have positive and significant relationship with family farming efficiency. The possible reason could be the responsibility of farming as well as household and commitment to own family well-being create a way for deferred gratification in family headed women that in turn it enhances the efficiency in family farming. However, the results are in consonance with findings of Birajdar Vikrant Madhukar (2012). 


\section{Farming commitment and family farming efficiency}

Farming commitment found to have positive and significant relationship with family farming efficiency due to the reason, as dedication and devotion increases in family headed women in achieving Excellency she will be committed to the work and focus her efforts to attain higher magnitude of efficiency in family farming. There are no related studies to support the relationship of farming commitment and family farming efficiency.

\section{Extension orientation and family farming efficiency}

Extension orientation found to have positive and significant relationship with family farming efficiency. The plausible reason might be due to the fact the inherent motivation of family headed women to achieve something and frequent participation in extension activities like discussions, meetings, field visits, krishimela and other activities under normal circumstances influenced and motivated her. Thus extension contact and participation might have strong bearing on the family farming efficiency. The findings are supported by the results of Rajashekhar Reddy (2006), Nehete et al., (2011), Birajdar Vikrant Madhukar (2012) and Rahul Pawar (2015).

\section{Family size and family farming efficiency}

Family size found to have a positive and significant relationship with family farming efficiency as the name itself reflects if the number of family members are more in household there will be more availability of family labour and promotes efficiency in utilizing the family labour and time in turn it enhanced family farming efficiency. The results are in consonance with findings of Lavanya (2010).

\section{Livestock possession and family farming efficiency}

Livestock possession has shown the positive and significant relationship with family farming efficiency. As livestock and crop husbandry are supplemental to each other it reduces the cost spent on purchase of inputs like manure, fodder etc, Because of fixed price, subsidy and assured marketing for the milk. Cash can be generated by selling milk products, manure and eggs regularly. In addition to supplying milk, meat eggs, wool and dung, animals, mainly bullocks are the major source of power for both drawers. The findings are in agreement with the findings of Lavanya (2010).

\section{Material possession and family farming efficiency}

Material possession found to have positive and significant relationship with family farming efficiency. It might be due to owning of agricultural implements by family headed women increases that pave a way for timely operations with own implements which in turn enhances the time use efficiency and reduces the cost of cultivation be reducing hiring charges. Related studies are not available to support the obtained findings.

\section{Credit orientation and family farming efficiency}

Credit orientation found to have positive and significant relationship with family farming efficiency. The reason might be due to the fact that family headed women taken up timely operations by availing crop loans through financial institutions. Hence, avoided incidence of pest \& disease and delayed sowing. Avoided exorbitant interest rate by money lenders and also family headed woman tries to enhance the efficiency with commitment to repay the loan. The results of 
the study are corroborated with the findings of Manivannan and Hema Tripathi (2005).

\section{Risk orientation and family farming efficiency}

Risk orientation found to have positive and significant relationship with family farming efficiency. As family headed women can deal with the risks associated in family farming which includes crop production, crop management, post-harvest management, allied enterprises management and also marketing. However, there are no studies available either to support or contradict the obtained result.

\section{Extent of contribution of personal, psychological and socio-economic characteristics to Family farming efficiency}

The results of extent of contribution of personal, psychological and socio-economic characteristics of family headed women to family farming efficiency are presented in Table 2.

The contribution of independent variables towards family farming efficiency of women headed households was assessed and illustrated in the Table 2. The findings conveyed that 12 out of 16 independent variables such as land holding, family size, livestock possession, material possession, achievement motivation, credit orientation, adjustability, mass media use, deferred gratification, risk orientation, farming commitment and extension orientation had contributed significantly towards family farming efficiency of women headed households.

The remaining variables had not contributed significantly towards variability in family farming efficiency. The $\mathrm{R}^{2}$ value indicated that all the 16 independent variables had contributed to the tune of 79.15 per cent of variation in family farming efficiency of women headed households.

The possible reason with regard to extent of contribution of independent variables to family farming efficiency of women headed households due to land holding, livestock possession, material possession, credit orientation, mass media use, deferred gratification, achievement motivation, risk orientation, adjustability, farming commitment and extension orientation characteristics of family headed women were the factors going to influence directly on family farming efficiency of women headed households. Independent variables have synergic effects to one another, helping each other to have a major extent of contribution to the family farming efficiency.

Direct, indirect and largest effects of selected personal, psychological and socioeconomic characteristics to family farming efficiency

Path analysis was done to find out a quantitative interpretation of direct and indirect effects of selected personal, psychological, socio-economic and communication characteristics of women, heading the farm family to their Family Farming Efficiency

The details of analysis comprising direct effect, total indirect effect, first and second largest indirect effects channeled through other factors on family farming efficiency are provided in Table 3 and figure 1.

Twelve variables having significant relationship with the family farming efficiency of women headed households were considered to compute the path analysis. 
Table.1 Relationship between personal, psychological and socio-economic characteristics of family headed women with their family farming efficiency

\begin{tabular}{|c|c|c|}
\hline Sl. No. & $\begin{array}{c}\text { Personal, Psychological and Socio-Economic } \\
\text { Characteristics }\end{array}$ & Correlation co-efficient (r) \\
\hline $\mathbf{X}_{1}$ & Age & $0.150^{\mathrm{NS}}$ \\
\hline $\mathbf{X}_{2}$ & Education & $0.110^{\mathrm{NS}}$ \\
\hline $\mathbf{X}_{3}$ & Annual Income & $0.020^{\mathrm{NS}}$ \\
\hline $\mathbf{X}_{4}$ & Land Holding & $0.377 * *$ \\
\hline $\mathbf{X}_{5}$ & Family Size & $0.203 *$ \\
\hline $\mathbf{X}_{6}$ & Livestock Possession & $0.200 *$ \\
\hline $\mathbf{X}_{7}$ & Material Possession & $0.216^{*}$ \\
\hline $\mathbf{X}_{8}$ & Achievement Motivation & $0.380 * *$ \\
\hline $\mathbf{X}_{9}$ & Credit Orientation & $0.209^{*}$ \\
\hline $\mathbf{X}_{10}$ & Adjustability & $0.268 * *$ \\
\hline $\mathbf{X}_{11}$ & Mass Media Use & $0.326 * *$ \\
\hline $\mathbf{X}_{12}$ & Deferred Gratification & $0.253 * *$ \\
\hline $\mathbf{X}_{13}$ & Scientific Orientation & $0.105^{\mathrm{NS}}$ \\
\hline $\mathbf{X}_{14}$ & Risk Orientation & $0.206^{*}$ \\
\hline $\mathbf{X}_{15}$ & Farming Commitment & $0.259 * *$ \\
\hline $\mathbf{X}_{16}$ & Extension Orientation & $0.305 * *$ \\
\hline
\end{tabular}

Table.2 Multiple regression analysis of independent variables with family farming efficiency of women headed households

\begin{tabular}{|c|c|c|c|c|}
\hline Sl. No. & Selected Factors & $\begin{array}{c}\text { Regression co- } \\
\text { efficient }(\mathbf{B})\end{array}$ & Standard Error & ' $\mathbf{t}$ ' Value \\
\hline $\mathbf{X}_{\mathbf{1}}$ & Age & 1.2183 & 1.2603 & $0.54^{\mathrm{NS}}$ \\
$\mathbf{X}_{\mathbf{2}}$ & Education & 0.0386 & 0.3369 & $0.11^{\mathrm{NS}}$ \\
$\mathbf{X}_{\mathbf{3}}$ & Annual Income & 1.7383 & 0.7853 & $0.72^{\mathrm{NS}}$ \\
$\mathbf{X}_{\mathbf{4}}$ & Land Holding & 0.4545 & 0.1443 & $3.15^{* *}$ \\
$\mathbf{X}_{\mathbf{5}}$ & Family Size & 0.1269 & 0.0532 & $2.38^{*}$ \\
$\mathbf{X}_{\mathbf{6}}$ & Livestock Possession & 0.7568 & 0.1282 & $3.96^{* *}$ \\
$\mathbf{X}_{\mathbf{7}}$ & Material Possession & 0.2820 & 0.1127 & $2.52^{* *}$ \\
$\mathbf{X}_{\mathbf{8}}$ & Achievement Motivation & 0.2688 & 0.1134 & $2.37^{*}$ \\
$\mathbf{X}_{\mathbf{9}}$ & Credit Orientation & 0.6256 & 0.1139 & $4.62^{* *}$ \\
$\mathbf{X}_{\mathbf{1 0}}$ & Adjustability & 0.9442 & 1.3183 & $2.21^{*}$ \\
$\mathbf{X}_{\mathbf{1 1}}$ & Mass Media Use & 0.4011 & 0.1919 & $2.09^{*}$ \\
$\mathbf{X}_{\mathbf{1 2}}$ & Deferred Gratification & 0.2638 & 0.6182 & $2.27^{*}$ \\
$\mathbf{X}_{\mathbf{1 3}}$ & Scientific Orientation & 0.3206 & 0.5457 & $0.59^{\mathrm{NS}}$ \\
$\mathbf{X}_{\mathbf{1 4}}$ & Risk Orientation & 0.4325 & 0.1751 & $2.47^{*}$ \\
$\mathbf{X}_{\mathbf{1 5}}$ & Farming Commitment & 0.1399 & 0.0475 & $2.94^{* *}$ \\
$\mathbf{X}_{\mathbf{1 6}}$ & Extension Orientation & 0.8349 & 0.1618 & $4.34^{* *}$ \\
\hline $\mathrm{R}^{2}=0.7915$ & & & & \\
$\mathrm{~F}=11.19 * *$ & & & & \\
$*$ Significant at 0.05 per cent level of probability & & & \\
$* *$ Significant at 0.01 per cent level of probability & & & \\
NS= Non-Significant & & &
\end{tabular}


Table.3 Direct, indirect and largest indirect effects of personal, psychological and socioeconomic characteristics of family headed women on family farming efficiency

\begin{tabular}{|c|c|c|c|c|c|c|}
\hline $\begin{array}{c}\text { Factor } \\
\text { No. }\end{array}$ & Factor & $\begin{array}{l}\text { Direct } \\
\text { Effect }\end{array}$ & Rank & $\begin{array}{c}\text { Total } \\
\text { Indirect } \\
\text { effect }\end{array}$ & Rank & $\begin{array}{c}\text { Three Largest Indirect } \\
\text { effects channeled } \\
\text { through }\end{array}$ \\
\hline \multirow[t]{3}{*}{$\mathbf{X 1}$} & \multirow[t]{3}{*}{ Family Size } & \multirow[t]{3}{*}{0.031} & & \multirow[t]{3}{*}{0.172} & & $0.064 X_{2}$ \\
\hline & & & XI & & VIII & $0.044 X_{3}$ \\
\hline & & & & & & $0.166 X_{7}$ \\
\hline \multirow[t]{3}{*}{$\mathrm{X} 2$} & \multirow[t]{3}{*}{ Land Holding } & \multirow[t]{3}{*}{0.227} & \multirow[t]{3}{*}{ I } & \multirow[t]{3}{*}{0.604} & & $0.028 \mathrm{X}_{3}$ \\
\hline & & & & & I & $0.069 X_{2}$ \\
\hline & & & & & & $0.022 X_{9}$ \\
\hline \multirow{3}{*}{ X3 } & \multirow{3}{*}{$\begin{array}{l}\text { Livestock } \\
\text { Possession }\end{array}$} & \multirow[t]{3}{*}{0.156} & \multirow[t]{3}{*}{ IV } & \multirow[t]{3}{*}{0.069} & & $0.028 X_{2}$ \\
\hline & & & & & XII & $0.007 \mathrm{X}_{12}$ \\
\hline & & & & & & $0.004 X_{1}$ \\
\hline \multirow[t]{3}{*}{ X4 } & \multirow{3}{*}{$\begin{array}{c}\text { Material } \\
\text { Possession }\end{array}$} & \multirow[t]{3}{*}{0.162} & \multirow[t]{3}{*}{ III } & \multirow[t]{3}{*}{0.368} & & $0.037 X_{2}$ \\
\hline & & & & & IV & $0.137 \mathrm{X}_{1}$ \\
\hline & & & & & & $0.192 X_{11}$ \\
\hline \multirow[t]{3}{*}{ X5 } & \multirow{3}{*}{$\begin{array}{c}\text { Credit } \\
\text { Orientation }\end{array}$} & \multirow[t]{3}{*}{0.177} & \multirow[t]{3}{*}{ II } & \multirow[t]{3}{*}{0.265} & & $0.034 X_{2}$ \\
\hline & & & & & V & $0.021 \mathrm{X}_{4}$ \\
\hline & & & & & & $0.025 X_{8}$ \\
\hline \multirow[t]{3}{*}{ X6 } & \multirow{3}{*}{$\begin{array}{l}\text { Mass Media } \\
\text { Use }\end{array}$} & \multirow[t]{3}{*}{0.104} & VII & 0.430 & & $0.156 X_{5}$ \\
\hline & & & & & II & $0.026 \mathrm{X}_{12}$ \\
\hline & & & & & & $0.076 \mathrm{X}_{8}$ \\
\hline $\mathbf{X} 7$ & Deferred & 0.056 & VIII & 0.187 & & $0.126 X_{8}$ \\
\hline & Gratification & & & & VII & $0.086 \mathrm{X}_{1}$ \\
\hline & & & & & & $0.083 \mathrm{X}_{11}$ \\
\hline X8 & Achievement & 0.012 & XII & 0.392 & & $0.031 \mathrm{X}_{9}$ \\
\hline & Motivation & & & & III & $0.027 X_{10}$ \\
\hline & & & & & & $0.024 X_{11}$ \\
\hline X9 & Risk & 0.051 & IX & 0.155 & & $0.041 \mathrm{X}_{10}$ \\
\hline & Orientation & & & & $\mathrm{X}$ & $0.018 \mathrm{X}_{11}$ \\
\hline & & & & & & $0.036 X_{4}$ \\
\hline X10 & Adjustability & 0.123 & VI & 0.145 & & $0.046 X_{9}$ \\
\hline & & & & & XI & $0.026 X_{11}$ \\
\hline & & & & & & $0.027 X_{8}$ \\
\hline X11 & Farming & 0.042 & $\mathrm{X}$ & 0.217 & & $0.142 \mathrm{X}_{1}$ \\
\hline & Commitment & & & & VI & $0.021 \mathrm{X}_{8}$ \\
\hline & & & & & & $0.172 X_{3}$ \\
\hline X12 & Extension & 0.136 & V & 0.169 & & $0.074 \mathrm{X}_{3}$ \\
\hline & Orientation & & & & IX & $0.037 \mathrm{X}_{10}$ \\
\hline & & & & & & $0.017 X_{2}$ \\
\hline
\end{tabular}

Residual effect $=0.208$ 
Fig.1 Direct, indirect and largest indirect effects of independent variables on family farming efficiency

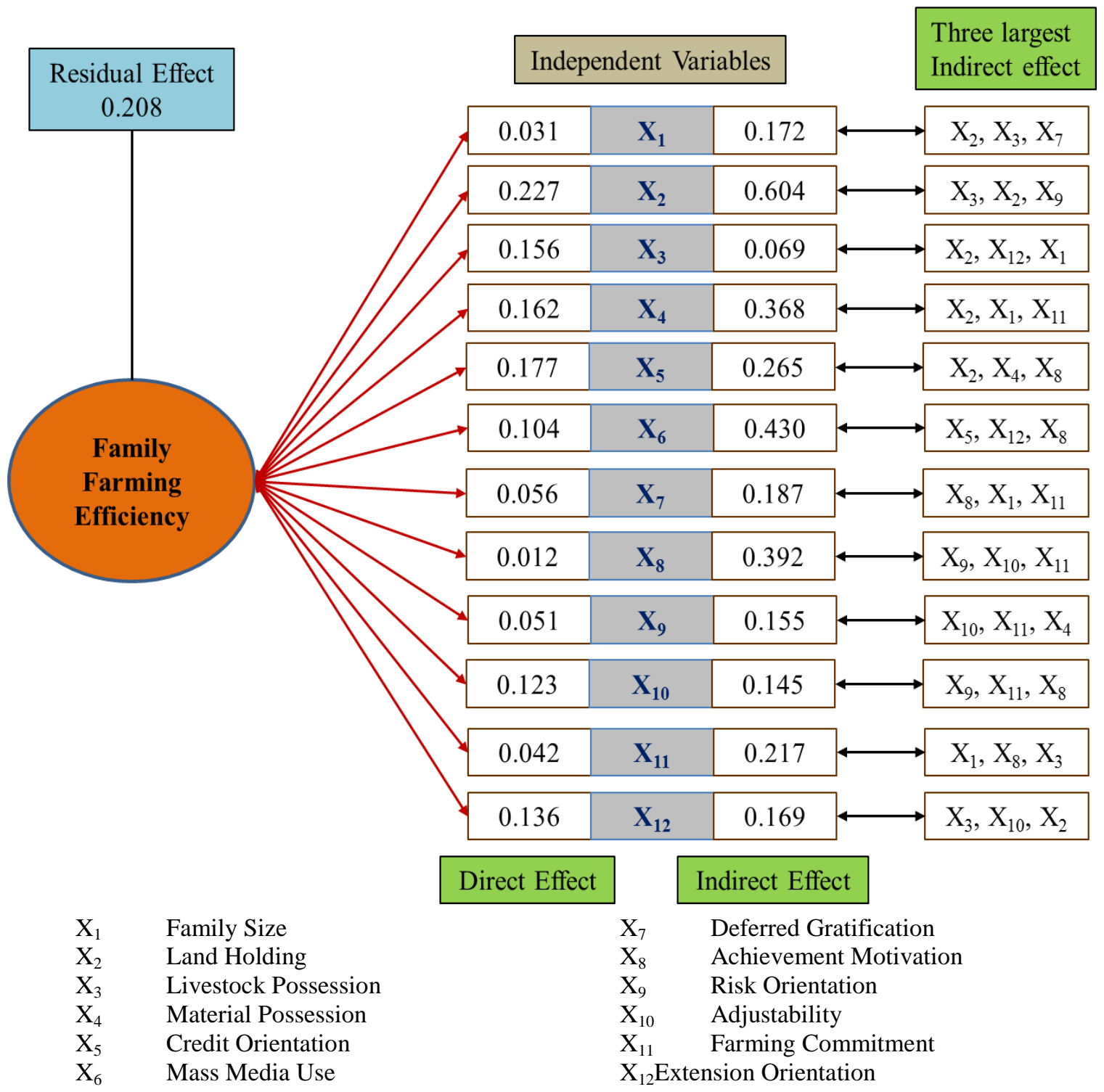

A clear observation of the results confirmed that 12 variables selected had positive direct effect on family farming efficiency. Ranking variables based on their direct effect revealed that land holding (X2) credit orientation (X5), material possession (X4) and livestock possession (X3) and extension orientation (X5) obtained five ranks in the same order. As regards to total indirect effects channeled through other variables for each of the selected independent variables, it was found substantial. Raking of indirect effect revealed that land holding (X2), mass media use(X6), achievement motivation(X8), material possession(X4)and credit orientation (X5) were the first five ranks in the same order.

The first largest indirect effect was channeled through land holding (X2) livestock possession (X3) and risk orientation(X9). The residual effect was found to be 0.208 , it indicated the quantum of unexplained variance or disturbance terms. 


\section{References}

Anonymous, 2011, Socio Economic and Caste Census Report, Press Information Bureau, Government of India, official website. http://secc.gov.in

Jose Graziano Da Silva., 2014, Family Farms are key to feeding the world. Rural 21Internatl. J. Rural Dev., 48(2): 6-7.

Rajashekhar Reddy, K. P., 2006, A Study on Management Efficiency of Sericulturists in North Karnataka. M.Sc. (Agri.) Thesis, Univ. Agric. Sci., Dharwad.

Basavaraj Gundappagol., 2014, Management efficiency of vegetable growers of Belgaum district. M.Sc. (Agri.) Thesis, Univ. Agric. Sci., Dharwad.
RAHUL PAWAR., 2015, Management Efficiency and Economic Performance of $B t$ Cotton Growers in Belagavi district. M.Sc. (Agri.) Thesis, Univ. Agric. Sci., Bangalore.

Nehete, N. C., Saiyad, A. S. and Badhe, D. K., 2011, Management efficiency of milk producers of Anand taluka of Gujarat State. J. Dairying,Foods and Home Sci., 30(1): $69-71$.

Birajdar Vikrant Madhukar., 2012, Management Efficiency of Cut Flower Growers. Ph. D. Thesis, Univ. Agric. Sci., Dharwad.

Manivannan, C. and Hema Tripathi., 2005, Management efficiency of dairy entrepreneurs. Indian Res. J. Extn.Edu., 7(2\&3): 44-51.

\section{How to cite this article:}

Harshitha, D., V.L. Madhu Prasad and Sanjay Yadav. 2019. Correlates of Family Farming Efficiency of Women Headed Households in Tumakuru District. Int.J.Curr.Microbiol.App.Sci. 8(11): 1573-1581. doi: https://doi.org/10.20546/ijcmas.2019.811.182 